\section{HPV-testing ved Stavanger universitetssjukehus}

Vi ønsker med dette å komme med en korreksjon til Steinar Sørbyes presentasjon i nr. 18/2010 (1) av egen artikkel om HPVtest (2). I innlegget kan man få inntrykk av at mRNA-testen (PreTect HPV-Proofer fra NorChip) som brukes ved Universitetssykehuset Nord-Norge, også er etablert som en diagnostisk test ved Stavanger universitetssjukehus. Dette er ikke tilfellet. Metoden er blitt tatt i bruk for et forskningsprosjekt, men er ikke i bruk for rutinetesting.

I januar 2010 startet vi et «HPV-metodeevalueringsprosjekt» der vi vil sammenlikne den kliniske spesifisiteten og sensitiviteten av to DNA-tester og to mRNAtester. I denne sammenlikningen inngår også PreTect HPV-Proofer fra NorChip. I likhet med firmaene for de andre metodene som er med i prosjektet, har vi i prøveperioden lånt et instrument og fått dekt reagensutgifter av Norchip.

Resultatene fra denne sammenlikningen er ikke ferdig, og vi synes det er uheldig dersom våre andre samarbeidspartnere skal få inntrykk av at vi har tatt et standpunkt og etablert en av metodene på det nåværende tidspunkt.

Irene T. Øvestad
Emiel Janssen
Kjell Kjellevold
Jan Baak
Stavanger universitetssjukehus
Litteratur
1. Sørbye S. Mer treffsikker HPV-test. Tidsskr Nor
Legeforen 2010; 130 : 1801.
2. Sørbye S. HPV mRNA test in women with minor
cervical lesions; experience of the University Hos-
pital of North Norway. J Virol Methods 2010, doi:
10.1016/j.jviromet.2010.07.011.

\section{Grove faktafeil i Tidsskriftet}

I Tidsskriftet nr. 18/2010 hevder gjesteskribenten Hans-Erik Dyvik Husby at foreningen ADHD Norge får mye av sin økonomiske støtte fra produsentene av Ritalin, Concerta og Strattera, og at organisasjonen Citizens Commission on Human Rights (CCHR), som Husby representerer, kontinuerlig er i kontakt med politi, fagmiljø og medier for å belyse dette forholdet (1).

ADHD Norge er ikke prinsipiell motstander av å motta sponsorinntekter, heller ikke fra legemiddelindustrien. Men det har aldri vært snakk om store beløp. I 2009 fikk vi kr 0, i 2008 fikk vi kr 320000 og i 2007 kr 10000 . Vårt totale budsjett/inntekter ligger på ca. kr 11000000 per år. Samlet for disse årene har vi mottatt støtte i størrelsesorden $1 \%$ av våre samlede inntekter.

Det er med en viss undring jeg konstaterer at Tidsskriftet formidler svært feil opplysninger om ADHD Norge, og det fra en person som bekjenner seg til Citizens Commission on Human Rights. På organisasjonens egen hjemmeside står det nemlig følgende: «CCHR was co-founded in 1969 by the Church of Scientology and Professor of Psychiatry Emeritus Dr. Thomas Szasz at a time when patients were being warehoused in institutions and stripped of all constitutional, civil and human rights» (2).

Det er fortsatt med samme undring jeg da konstaterer at Tidsskriftet, som viser både til Redaktørplakaten og Vær varsom-plakaten, ikke etterlever sitt presseetiske fundament ved å la ADHD Norge få balansere bildet slik det beskrives i Vær varsom-plakaten punkt 4.14:

«4.14. De som utsettes for sterke beskyldninger skal såvidt mulig ha adgang til samtidig imøtegåelse av faktiske opplysninger. Debatt, kritikk og nyhetsformidling må ikke hindres ved at parter ikke er villig til å uttale seg eller medvirke til debatt.» Når Tidsskriftet ikke ga mulighet for denne korreksjonen i nummeret der de gale påstandene ble fremsatt, er jeg likevel tilfreds med at min tilbakemelding til redaksjonen formidles i ettertid.

\section{Tor Eikeland \\ ADHD Norge \\ Litteratur \\ 1. Husby HD. Gjøkungen i medisinen. Tidsskr Nor Legeforen 2010; 130: 1892 \\ 2. The Citizens Commission on Human Rights. www.cchr.org/about-us/what-is-cchr.html (19.10.2010).}

\section{Prinsene fra Serendip og medisinske gjennombrudd}

Et gammelt persisk eventyr om de tre prinsene fra Serendip (persisk for Sri Lanka) forteller blant annet hvordan de tre brødrene er i stand til å beskrive en enøyd og halt kamel som mangler en tann og bærer en gravid kvinne, ennskjønt de ikke har sett kamelen og kun baserer seg på spor der den har gått. Fortellingen ga opphav til det engelske ordet «serendipity» - evnen til å gjøre en ny oppdagelse mens man egentlig er opptatt av noen annet. Mange mener at nettopp «serendipity» er en viktig komponent i mange vitenskapelige oppdagelser og gjennombrudd.

I Tidsskriftet nr. 18/2010 beskrives, illustrert av en kasuistikk, behandling av infantile hemangiomer med propranolol (1). Den første beskrivelsen av denne behandlingen er bare to år gammel (2) og er et morsomt eksempel nettopp på «serendipity». Tilfeldighetenes spill ville det slik at barn som fikk propranolol for sin hjertelidelse også hadde hemangiom. Kort tid etter at behandlingen var startet, observerte man begynnende involusjon av hemangiomet. Her ligger etter min oppfatning «lærepengen» for mange av oss. Det er fort gjort å avvise slike observasjoner som tilfeldige og på den måten gå glipp av viktig erkjennelse. Oppdagelsen av fototerapi som virksom behandling for gulsott hos nyfødte tilskrives en observant engelsk sykepleier som la merke til at et ikterisk barn som hadde vært eksponert for skarpt sollys hadde gulere hud under bleien enn på lyseksponerte områder. Hvor mange hadde observert det samme fenomenet før, men likevel ikke undret seg over det?

Kunnskapsbasert medisin er uten tvil et av de aller største metodologiske gjennombruddene i moderne tid. Men når den omtales, kan man av og til få inntrykk av at alle andre tilnærminger til kunnskapssøken er sekunda vare. Derfor bør historien om hemangiomene og propranolol være en påminnelse om at det fortsatt er rom for observante leger med undrende sinn. Utvilsomt ligger det fortsatt mange uoppdagede kunnskapsskatter og venter på vitenskapens Espen Askeladd.

\section{Thor Willy Ruud Hansen \\ Oslo}
Litteratur
1. Guldbakke KK, Rørdam O-M, Huldt-Nystrøm T et al. Behandling av infantilt hemangiom med prop- ranolol. Tidsskr Nor Legeforen 2010; 130: 1822-4.
2. Léauté-Labréze C, Dumas de la Roque E, Hubiche $T$ et al. Propranolol for severe hemangiomas of infancy. N Engl J Med 2008; 358: 2649-51.

\section{Syfilis og transfusjon}

I Tidsskriftet nr. 8/2010 omtalte Jenum og medarbeidere en hendelse der syfilis ble påvist hos en etablert norsk blodgiver da denne byttet blodbank (1). Alle gjeldende rutiner for syfilistesting var fulgt. Et ekspertutvalg under Helsedirektoratet har vurdert 